\title{
APLIKASI PEWARNAAN GRAF UNTUK OPTIMALISASI PENGATURAN TRAFFIC LIGHT DI SUKOHARJO
}

\author{
Cahyo Heny Meiliana ${ }^{1}$, Dwi Maryono ${ }^{2}$ \\ ${ }^{1}$ Mahasiswa Prodi Pendidikan Matematika FKIP UNS \\ J1. Ir. Sutami 36A Surakarta \\ ${ }^{2}$ Dosen Prodi PTIK FKIP UNS \\ Kampus V FKIP UNS di Jl. Ahmad Yani 200, Pabelan, Surakarta \\ email:dwimarus@yahoo.com
}

\begin{abstract}
ABSTRAK
Kemacetan lalu lintas menjadi permasalahan yag dihadapi berbagai kota di Indonesia. Salah satu solusinya adalah dengan menggunakan lampu Traffic Light. Keberadaan lampu Traffic Light sangat membantu untuk menertibkan pengguna jalan, namun dalam banyak kasus kurang optimal, terkait dengan penentuan arus mana yang harus merah maupun hijau dan berapa lama masing-masing. Untuk mengatasi masalah tersebut digunakan pendekatan graf dengan aplikasi pewarnaan titik sebagai penyelesaian masalah penjadwalan. Algoritma yang digunakan adalah Welch-Powell. Kasus trafic Light diambil dair beberapa titik di Kabupaten Sukoharjo, meliputi Simpang 3 Bekonang, Simpang 4 Gayam, dan Simpang 5 Sukoharjo.

Dari pembahasan diperoleh hasil bahwa penggunaan pewarnaan graf dengan algoritma Welch-Powell mampu meningkatkan efektifitas traffic light dilihat dari durasi total lampu hijau dan merah menyala.
\end{abstract}

Kata Kunci: Traffic Light, Penjadwalan, Pewarnaan Graf, Welch-Powell

\section{PENDAHULUAN}

dijumpai di kota-kota besar di Indonesia. Beberapa faktor penyebab kemacetan adalah kurangnya disiplin pengguna jalan dan volume kendaraan yang semakin bertambah. Permasalahan ini dapat diselesaikan salah satunya dengan pengaturan lampu lalu lintas (traffic light).

Lampu lalu lintas (menurut UU no. 22/2009 tentang Lalu Lintas dan Angkutan Jalan: alat pemberi isyarat lalu lintas atau APILL) adalah lampu yang mengendalikan arus lalu lintas yang terpasang di persimpangan jalan, tempat penyeberangan pejalan kaki (zebra crosss), dan tempat arus lalu lintas lainnya. Lampu ini menandakan waktu kendaraan harus berjalan dan berhenti secara bergantian dari berbagai arah. Lampu lalu lintas yang tersedia di persimpangan jalan mempunyai beberapa tujuan antara lain menghindari hambatan karena adanya perbedaan arus jalan bagi pergerakan kendaraan, memfasilitasi pejalan kaki agar dapat menyebrang dengan aman dan mengurangi tingkat kecelakaan yang diakibatkan oleh tabrakan karena perbedaan arus jalan. Karena fungsinya yang begitu penting maka lampu lalu lintas harus dapat dikendalikan atau dikontrol dengan semudah mungkin demi memperlancar arus lalu lintas di suatu persimpangan jalan.

$$
\text { masalah Kemacetan lalu lintas } \begin{array}{r}
\text { merupakan } \\
\text { yang }
\end{array}
$$

Sebagian besar pengaturan lampu lalu lintas (traffic light) pada saat ini masih kurang optimal karena pada persimpangan jalan banyak ditemui lampu lalu lintas (traffic light) dengan durasi lampu hijau yang singkat dan lampu merah yang lama. Misalkan beberapa persimpangan di Kabupaten Sukoharjo. Hal ini menyebabkan terjadinya peningkatan antrian kendaraan pada persimpangan tersebut.

Teori graf merupakan pokok bahasan yang mempunyai manfaat besar dalam kehidupan sehari-hari. Salah satu bagian dari teori graf adalah pewarnaan graf. Ada tiga macam pewarnaan graf, yaitu pewarnaan simpul, pewarnaan sisi, dan pewarnaan wilayah (region). Salah satu upaya untuk mengoptimalkan pengaturan lampu lalu lintas (traffic light) pada persimpangan jalan adalah dengan pewarnaan simpul menggunakan algoritma Welch-Powell.

Penyelesaian masalah lampu lalu lintas (traffic light) dapat ditinjau dalam perspektif graf, yaitu dengan merepresentasikan persimpangan dalam bentuk graf. Simpul graf menunjukkan arah perjalanan yang diperbolehkan dari jalan $X$ menuju Y, sedangkan sisi graf menunjukkan arah perjalanan yang tidak boleh dilakukan secara bersamaan. Selanjutnya menyelesaikannya dengan metode pewarnaan simpul menggunakan algoritma Welch-Powell. Penyelesaian ini akan 
menghasilkan arus-arus yang dapat berjalan secara bersamaan, selain itu juga diperoleh alternatif durasi siklus baru.

Algoritma ini telah digunakan Detty dkk (2012) untuk mengoptilakan lalu lintas di Simpang Empat Kalimas Bekasi Timur, sedangkan Riwinoto, dkk (2010) juga menggunakan algoritma serupa di Kota Depok. Sedangkan pada artikel ini studi kasus diambil di Kabupaten Sukoharjo. Hasil perhitungan durasi siklus baru akan dibandingkan dengan siklus waktu data sekunder dari Dinas Perhubungan Kabupaten Sukoharjo tahun 2014 dan diharapkan bisa menjadi solusi bagi penggunaan jalan dalam rangka mempercepat masa tunggu ketika lampu merah menyala.

Efektivitas pengaturan lampu lalu lintas yag baru diukur dari seberapa besar peningkatan durasi total durasi lampu hijau dan penurunan total durasi lampu merah dibandingkan dengan data sekunder yang telah diperoleh dalam satu siklus.

\section{LANDASAN TEORI Teori Graf}

Sebuah graf $G$ terdiri dari suatu himpunan $V$ yang merupakan vertex-vertex (simpul-simpul) dan suatu himpunan $E$ dari sisisisi sedemikian rupa sehingga setiap sisi dikaitkan dengan pasangan simpul tak terurut. Jika terdapat sebuah sisi $e$ yang menghubungkan simpul $v$ dan $w$, dapat dinyatakan dengan $e=$ $(v, w)$ atau $e=(w, v)$. Dalam konteks ini, $(v, w)$ menyatakan sebuah sebuah sisi antara simpul $v$ dan simpul $w$ dalam sebuah graf dan bukan sebuah pasangan terurut.

(Richard Johnsonbaugh, 2002: 3)

Graf disajikan dalam bentuk diagram, dimana simpul (vertex) disajikan berupa titik dan dapat dinotasikan dengan huruf seperti $,,, \ldots,, \ldots$, atau dengan bilangan asli $1,2,3, \ldots$, atau gabungan keduanya. Sedangkan sisi (edge) disajikan berupa garis lurus atau garis lengkung yang menghubungkan dua buah simpul $($, ) dan dapat dinotasikan dengan $(=$ $1,2,3, \ldots$, ). Untuk lebih jelasnya dapat dilihat contoh graf seperti pada Gambar 1 berikut:
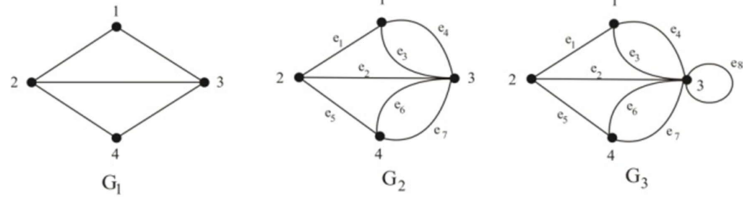

Gambar 1. Contoh Graf adalah graf dengan himpunan simpul dan sisi adalah :

$=\{1,2,3,4\}$

$=\{(1,2),(1,3),(2,3),(2,4),(3,4)\}$

adalah graf dengan himpunan simpul dan sisi adalah :

$=\{1,2,3,4\}$

$=\{(1,2),(2,3),(1,3),(1,3),(2,4),(3,4)\}$

$=\{,,,, \quad, \quad\}$

adalah graf dengan himpunan simpul dan sisi adalah :

$=\{1,2,3,4\}$

$=$

$\{(1,2),(2,3),(1,3),(1,3),(2,4),(3,4),(3,4),(3,3)\}$

$=\{,,,,,, \quad\}$

Graf yang dibahas dalam penelitian ini adalah graf yang tidak berarah, di mana setiap sisinya tidak mempunyai orientasi arah. Tandanya adalah urutan pasangan simpul yang dihubungkan oleh sisi tidak diperhatikan. Jadi, $\left(v_{i}\right.$ , $\left.v_{k}\right)=\left(v_{k}, v_{i}\right)$ adalah sisi yang sama.

Berikut ini beberapa istilah dalam Graf, menurut Munir (2005)

1) Sebuah sisi yang menghubungkan sepasang simpul yang sama yakni $(, \quad)$ disebut loop dan dua buah atau lebih sisi yang mempunyai simpul-simpul ujung yang sama disebut sisi berganda (multiple edges atau parallel edges).

Pada Gambar 1 dapat dilihat bahwa graf tidak memiliki loop maupun sisi berganda sedangkan graf tidak memiliki loop tetapi memiliki sisi berganda yaitu, dan, . Pada graf memiliki loop yaitu dan sisi berganda yaitu, dan , .

Graf yang tidak mengandung gelang maupun sisi ganda dinamakan graf sederhana.

2) Dua buah simpul pada graf dikatakan bertetangga bila kedua simpul tersebut terhubung langsung. Dapat kita sebut

bertetangga dengan pada graf jika $(, \quad)$ adalah sisi pada sebuah graf .

3) Untuk sebarang sisi $=($, ) dikatakan bersisian dengan simpul atau bersisian dengan simpul

Derajat dari sebuah simpul ( $=$ $1,2,3, \ldots$, ) dalam graf adalah jumlah sisi yang bersisian dengan, dengan loop dihitung dua kali. Bila jumlah sisi yang bersisian dengan jumlah simpul adalah maka derajad dari adalah , sehingga $(\quad)=$. 


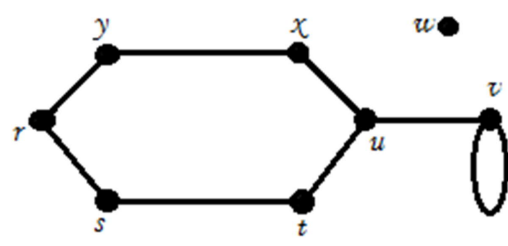

Gambar 2. Graf $G_{4}$

Derajat masing-masing simpul graf $G_{4}$ pada Gambar 2 adalah

$$
\begin{aligned}
& \mathrm{d}(r)=2, \mathrm{~d}(s)=2, \mathrm{~d}(t)=2, \mathrm{~d}(u)=3, \mathrm{~d}(v) \\
& =3, \mathrm{~d}(w)=0, \mathrm{~d}(x)=2, \mathrm{~d}(y)=2 .
\end{aligned}
$$

\section{Pewarnaan Simpul}

Menurut Koh Khee Meng, Dong Fengming dan Tay Eng Guan (2006), misalkan $G$ adalah graf dan $k$ adalah bilangan bulat positif. Suatu pewarnaan- $k$ untuk graf $G$ adalah cara mewarnai simpul pada graf $G$ dengan sebanyak $k$-warna sedemikian sehingga simpul yang adjacent diwarnai dengan warna yang berbeda.

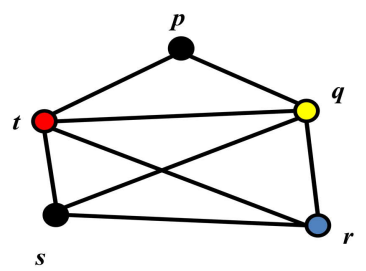

Gambar 3 Pewarnaan simpul graf $G$

Misalkan $G$ adalah graf. Bilangan Kromatik dari graf $G$ dinyatakan dengan ( ) adalah jumlah warna minimum yang digunakan untuk mewarnai simpul pada graf $G$ sedemikian sehingga simpul yang adjacent diwarnai dengan warna yang berbeda.

Pada graf $G$ pada Gambar 3 mempunyai bilangan kromatik ()$=4$

\section{Algoritma Welch-Powell}

Algoritma Welch Powell digunakan untuk mewarnai simpul suatu graf berdasarkan derajat tertinggi dari simpul-simpulnya. Menurut Munir (2007), algoritma Welch Powell adalah sebagai berikut :

1. Urutkan simpul-simpul dari graf $\mathrm{G}$ dalam derajat yang menurun (urutan seperti ini mungkin tidak unik karena beberapa simpul mungkin berderajat sama)

2. Gunakan satu warna untuk mewarnai simpul pertama (yang mempunyai derajat tertinggi) dan simpul-simpul lain (dalam urutan yang berurut) yang tidak bertetangga dengan simpul pertama ini.
3. Mulai lagi dengan simpul derajat tertinggi berikutnya di dalam daftar terurut yang belum diwarnai dan ulangi proes pewarnaan simpul dengan menggunakan warna kedua.

4. Ulangi penambahan warna-warna sampai semua simpul telah diwarnai.

Algoritma Welch Powell tidak selalu memberikan jumlah warna minimum dalam pewarnaan graf, tetapi memberikan batas atas jumlah warna yang dapat dipakai untuk mewarnai suatu graf.

Contoh pewarnaan graf $G$ pada Gambar 4 menggunakan algoritma Welch Powell

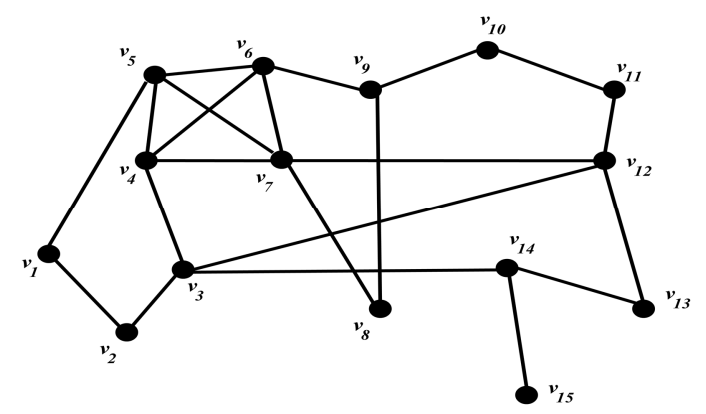

Gambar 4. Graf G

Langkah-langkah penyelesaiannya sebagai berikut:

1. Jumlah simpul graf $G$ pada gambar 3.2 adalah 15. Urutan simpul dari derajat yang tertinggi hingga yang terendah, seperti pada Tabel 1.

2. Karena $v_{7}$ mempunyai derajat tertinggi, maka simpul $v_{7}$ dapat diwarnai dengan warna biru, kemudian simpul $v_{9}, v_{14}, v_{1}, v_{11}$ yang tidak saling adjacent dengan $v_{7}$ juga diwarnai dengan biru.

3. Selanjutnya mewarnai simpul $v_{3}$ yang merupakan simpul dengan derajat tertinggi berikutnya dengan warna hijau dan $v_{5}, v_{8}$, $v_{10}, v_{13}, v_{15}$ yang adjacent dengan $v_{3}$ juga diwarnai warna hijau.

4. Langkah berikutnya mewarnai simpul $v_{4}$ sebagai simpul dengan derajat tertinggi berikutnya dengan warna merah begitu juga dengan simpul $v_{2}$ dan $v_{12}$ yang tidak saling adjacent dengan $v_{4}$.

5. Simpul terakhir yang belum diwarnai adalah $v_{6}$. Karena simpul ini saling adjacent dengan simpul $v_{4}, v_{5}$, dan $v_{7}$ maka warna yang digunakan harus berbeda dengan simpulsimpul tersebut. Jadi $v_{6}$ diwarnai dengan warna kuning.

Lihat Gambar 5 untuk lebih jelasnya 
Tabel 1 Jumlah derajat simpul graf $G$

\begin{tabular}{|l|l|l|l|l|l|l|l|l|l|l|l|l|l|l|l|}
\hline Simpul & $v_{7}$ & $v_{3}$ & $v_{4}$ & $v_{5}$ & $v_{6}$ & $v_{12}$ & $v_{9}$ & $v_{14}$ & $v_{1}$ & $v_{2}$ & $v_{8}$ & $v_{10}$ & $v_{11}$ & $v_{13}$ & $v_{15}$ \\
\hline Derajat Simpul & 5 & 4 & 4 & 4 & 4 & 4 & 3 & 3 & 2 & 2 & 2 & 2 & 2 & 2 & 1 \\
\hline
\end{tabular}

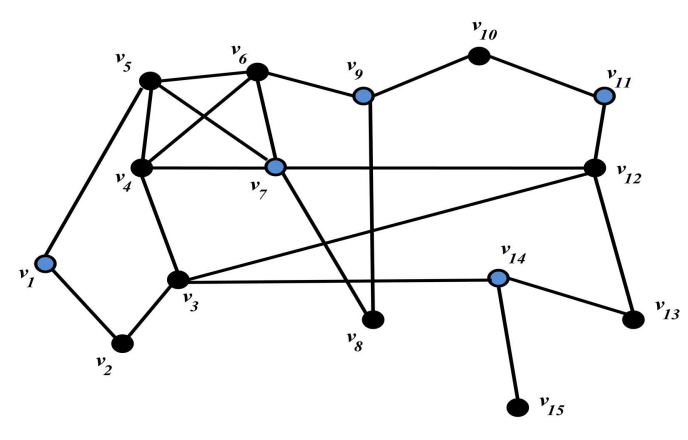

Pewarnaan Pertama

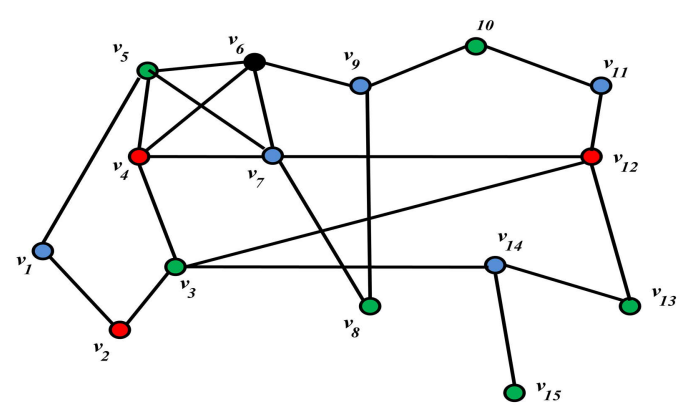

Pewarnaan Ketiga

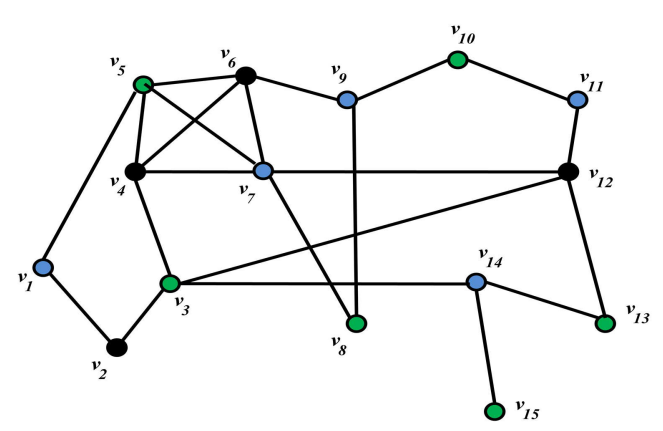

Pewarnaan Kedua

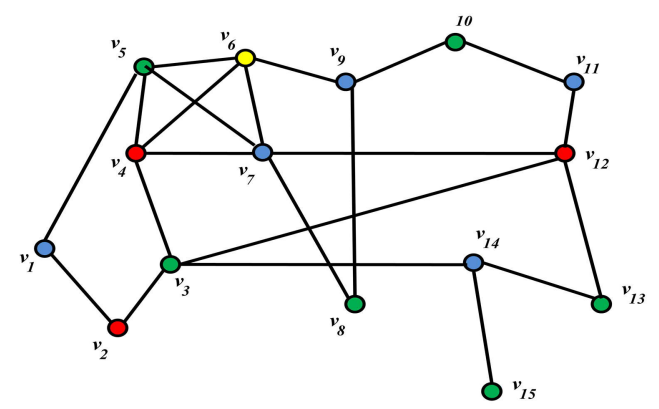

Pewarnaan Terakhir

Gambar 5 Langkah-langkah pewarnaan simpul graf $G$ dengan Algoritma Welch Powell

\section{PEMBAHASAN}

\section{Aplikasi Pewarnaan Simpul pada Traffic Light di Persimpangan Jalan}

Traffic Light yang tersedia di persimpangan jalan mempunyai beberapa tujuan antara lain menghindari hambatan karena adanya perbedaan arus jalan bagi pergerakan kendaraan, memfasilitasi pejalan kaki agar dapat menyebrang dengan aman dan mengurangi tingkat kecelakaan yang diakibatkan oleh tabrakan karena perbedaan arus jalan. Namun traffic light juga emiliki beberapa permasalahan yang perlu diselesaikan, salah satunya pengaturan durasi lampu merah dan hijau. Permasalahan ini dapat dikaji pengaturannya menggunnakan prinsip pewarnaan simpul.

Untuk lebih jelasnya berikut adalah langkahlangkah aplikasi pewarnaan simpul pada traffic light di persimpangan jalan.

1. Mentransformasikan persimpangan jalan beserta arusnya ke bentuk graf. Simpul merepresentasikan arus dan garis merepresentasikan arus-arus yang tidak boleh berjalan bersamaan, yang selanjutnya simpulsimpul tersebut saling dihubungkan.

2. Mewarnai setiap simpul pada graf dengan menggunakan algoritma Welch Powell. Selain untuk mengetahui arus mana saja yang bisa berjalan bersamaan, diperoleh juga jumlah bilangan kromatik yang akan bermanfaat pada tahap berikutnya.

3. Menentukan alternatif penyelesaian durasi lampu hijau dan lampu merah menyala dengan siklus waktu tertentu. Hal ini dapat dilakukan dengan membagi satu siklus yang tediri dari total durasi lampu merah dan lampu hijau menyala dengan bilangan kromatik yang telah diperoleh dari langkah 2 , hasil pembagiannya menunjukkan durasi lampu hijau menyala. Adapun durasi siklus waktu pada setiap persimpangan yang diteliti merujuk pada data sekunder dari Dinas Perhubungan Kabupaten Sukoharjo tahun 2014.

Berikut akan dipaparkan penyelesaian kasus pengaturan traffic light pada beberapa persimpangan di Sukoharjo. 


\section{Simpang 3 Bekonang} Bekonang

Pada Gambar 6 diilustrasikan simpang 3

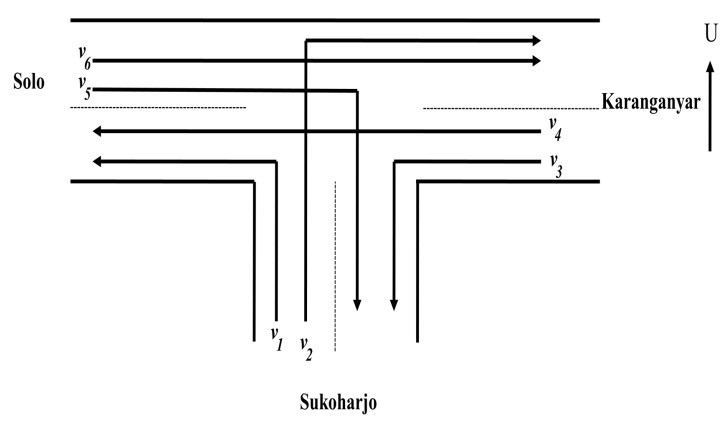

Gambar 6 Ilustrasi Arus Simpang 3 Bekonang

\section{Keterangan:}

$v_{1}=$ arus dari Sukoharjo menuju Solo

$v_{2}=$ arus dari Sukoharjo menuju Karanganyar

$v_{3}=$ arus dari Karanganyar menuju Sukoharjo

$v_{4}=$ arus dari Karanganyar menuju Solo

$v_{5}=$ arus dari Solo menuju Sukoharjo

$v_{6}=$ arus dari Solo menuju Karanganyar

Arus-arus yang uncompatible (tidak boleh berjalan bersamaan) adalah

a. Arus $v_{2}$ tidak boleh berjalan bersamaan dengan $v_{4}, v_{5}, v_{6}$

b. Arus $v_{4}$ tidak boleh berjalan bersamaan dengan $v_{2}, v_{5}$

c. Arus $v_{5}$ tidak boleh berjalan bersamaan dengan $v_{2}, v_{4}$

d. Arus $v_{6}$ tidak boleh berjalan bersamaan dengan $v_{2}$

Data traffic light Simpang 3 Bekonang dari Dinas Perhubungan Kabupaten Sukoharjo sebagai berikut.

Tabel 2

Data sekunder simpang 3 Bekonang

\begin{tabular}{|c|c|c|c|c|}
\hline Kaki simpang & Selatan & Timur & Barat & Total \\
\hline Merah & 46 & 42 & 46 & 134 \\
\hline Hijau & 18 & 22 & 18 & 58 \\
\hline Total & 64 & 64 & 64 & 192 \\
\hline
\end{tabular}

Langkah-langkah penyelesaian perhitungan traffic light di simpang 3 Bekonang sebagai berikut:

1) Mentransformasi simpang 3 Bekonang ke bentuk graf sebagai berikut:

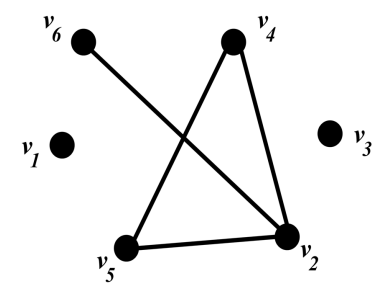

Gambar 7 Graf Simpang 3 Bekonang

Dari transformasi graf di atas diketahui simpul $v_{1}$ dan $v_{3}$ merupakan simpul asing yaitu simpul yang tidak saling terhubung dengan simpul lain, sehingga arus yang dinyatakan dengan simpul $v_{1}$ dan $v_{3}$ dapat berlangsung beriringan dengan arus lain atau dapat berlaku terus lampu hijau.

2) Mewarnai graf dengan algoritma WelchPowell untuk mencari bilangan kromatik. Dengan menggunakan algoritma Welch Powell dihasilkan pewarnaan graf sebagai berikut:

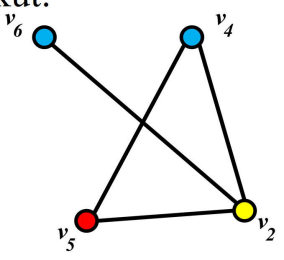

Gambar 8 Hasil pewarnaan graf pada simpang 3 Bekonang

Dari pewarnaan graf di atas diperoleh bilangan kromatik $=3$. Untuk kasus pada simpang 3 Bekonang, simpul $v_{6}$ tidak saling adjacent dengan simpul $v_{4}$ dan $v_{5}$ sehingga warna simpul $v_{6}$ bisa diseragamkan dengan simpul $v_{4}$ atau $v_{5}$. Hal ini akan berpengaruh pada penyelesaian arus yang dapat berjalan secara bersamaan. Penyelesaian arus-arus yang dapat berjalan bersamaan disajikan dalam Tabel 3 berikut.

Tabel 3

Warna simpul graf simpang 3 Bekonang

\begin{tabular}{|c|c|}
\hline Warna & Simpul \\
\hline Kuning & $v_{2}$ \\
\hline Biru & $v_{4}, v_{6}$ \\
\hline Merah & $v_{5}, v_{6}$ \\
\hline
\end{tabular}

Dari Tabel 3 di atas dapat dibuat 3 partisi pengaturan lampu, di mana pada partisi pertama, arus $v_{2}$ berjalan sendiri, pada partisi kedua, arus $v_{4}$ akan berjalan bersama arus $v_{6}$, dan pada Partisi ketiga, arus $v_{5}$ akan berjalan bersama arus $v_{6}$ 
3) Menentukan alternatif penyelesaian durasi lampu merah dan lampu menyala.

Berdasarkan data sekunder, durasi waktu satu siklus 64 detik, setelah dilakukan pembagian dengan bilangan kromatik $=3$, diperoleh durasi lampu hijau menyala yaitu 21.33 detik dan durasi lampu merah menyala yaitu 42.67 detik. Namun untuk $v_{6}$ yang dapat berjalan bersamaan dengan $v_{4}$ dan $v_{5}$ maka durasi lampu hijau akan bertambah menjadi 42.66 detik dan durasi lampu merah menyala berkurang menjadi 21.34 detik. Data traffic light baru hasil perhitungan disajikan pada Tabel 4.

Selanjutnya data baru durasi lampu hijau dan merah untuk traffic light simpang 3 Bekonang pada Tabel 5.

Tabel 4

Penyelesaian traffic light simpang 3 Bekonang

\begin{tabular}{|c|c|c|c|c|c|c|}
\hline $\begin{array}{c}\text { Simpu } \\
1\end{array}$ & $v_{1}$ & $v_{2}$ & $v_{3}$ & $v_{4}$ & $v_{5}$ & $v_{6}$ \\
\hline Merah & 0 & 42.6 & 0 & 42.6 & 42.6 & 21.3 \\
& & 7 & & 7 & 7 & 4 \\
\hline \multirow{2}{*}{ Hijau } & 6 & 21.3 & 6 & 21.3 & 21.3 & 42.6 \\
& 4 & 3 & 4 & 3 & 3 & 6 \\
\hline
\end{tabular}

Tabel 5

Data baru traffic light simpang 3 Bekonang

\begin{tabular}{|c|c|c|c|c|}
\hline $\begin{array}{c}\text { Kaki } \\
\text { simpang }\end{array}$ & Selatan & Timur & Barat & Total $_{\text {simpang 5 }}$ \\
\hline Merah & 42.67 & 42.67 & 21.34 & 106.68 \\
\hline Hijau & 21.33 & 21.33 & 42.66 & 85.32 \\
\hline Total & 64 & 64 & 64 & 192 \\
\hline
\end{tabular}

Berdasarkan durasi lampu merah dan lampu hijau di simpang 3 Bekonang dapat diketahui bahwa data baru hasil penyelesaian pewarnaan simpul dengan algoritma Welch Powell lebih efektif daripada data sekunder dari Dinas Perhubungan Kabupaten Sukoharjo tahun 2014. Berikut disajikan tabel data sekunder dan data baru.

Tabel 6

Data Sekunder dan data baru traffic light simpang 3 Bekonang

\begin{tabular}{|c|c|c|c|c|}
\hline \multirow{2}{*}{$\begin{array}{c}\text { Kaki } \\
\text { Simpang }\end{array}$} & \multicolumn{2}{|c|}{$\begin{array}{c}\text { Data } \\
\text { Sekunder }\end{array}$} & \multicolumn{2}{c|}{ Data Baru } \\
\cline { 2 - 5 } & Merah & Hijau & Merah & Hijau \\
\hline Selatan & 46 & 18 & 42.67 & 21.33 \\
\hline Timur & 42 & 22 & 42.67 & 21.33 \\
\hline
\end{tabular}

\begin{tabular}{|c|c|c|c|c|} 
Barat & 46 & 18 & 21.34 & 42.66 \\
\hline Total & $\mathbf{1 3 4}$ & $\mathbf{5 8}$ & $\mathbf{1 0 6 . 6 8}$ & $\mathbf{8 5 . 3 2}$ \\
\hline
\end{tabular}

Durasi total lampu hijau menyala dari data sekunder adalah 58 detik, sedangkan dengan pewarnaan simpul durasi total lampu hijau menyala adalah 85.32 detik. Tingkat efektivitasnya yaitu:

$$
=\frac{85.3258}{58} \times 100 \%=47.10 \%
$$

Durasi total lampu merah menyala dari data sekunder adalah 134 detik, sedangkan dengan pewarnaan simpul durasi total lampu merah menyala adalah 106.68 detik. Tingkat efektivitasnya yaitu:

$$
=\frac{134106.68}{134} \times 100 \%=20.39 \%
$$

Jadi untuk kasus simpang 3 Bekonang durasi lampu hijau menyala akan meningkat sebesar $47.10 \%$ sedangkan durasi lampu merah menyala dapat dikurangi sebesar $20.39 \%$.

\section{Simpang 4 Gayam}

Berikut disajikan ilustrasi simpang 4 Gayam.

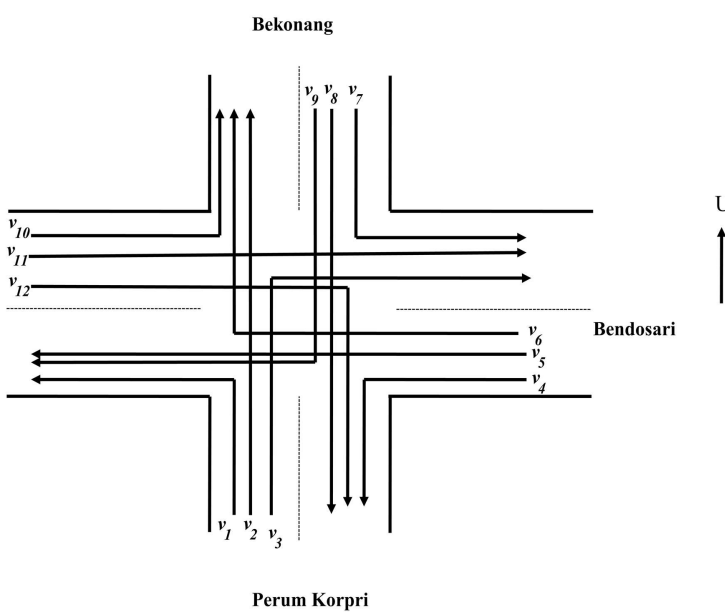

Gambar 9. Ilustrasi Arus Simpang 4 Gayam

\section{Keterangan:}

$v_{1}=$ arus dari Perum Korpri menuju simpang 5

$v_{2}=$ arus dari Perum Korpri menuju Bekonang

$v_{3}=$ arus dari Perum Korpri menuju Bendosari

$v_{4}=$ arus dari Bendosari menuju Perum Korpri

$v_{5}=$ arus dari Bendosari menuju simpang 5

$v_{6}=$ arus dari Bendosari menuju Bekonang

$v_{7}=$ arus dari Bekonang menuju Bendosari

$v_{8}=$ arus dari Bekonang menuju Perum Korpri

$v_{9}=$ arus dari Bekonang menuju simpang 5

Arus-arus yang uncompatible (tidak boleh berjalan bersamaan) adalah 
a. Arus $v_{2}$ tidak boleh berjalan bersamaan dengan $v_{5}, v_{6}, v_{9}, v_{11}, v_{12}$.

b. Arus $v_{3}$ tidak boleh berjalan bersamaan dengan $v_{5}, v_{6}, v_{8}, v_{9}, v_{11}, v_{12}$

c. Arus $v_{5}$ tidak boleh berjalan bersamaan dengan $v_{2}, v_{3}, v_{8}, v_{9}, v_{12}$.

d. Arus $v_{6}$ tidak boleh berjalan bersamaan dengan $v_{2}, v_{3}, v_{8}, v_{9}, v_{11}, v_{12}$

e. Arus $v_{8}$ tidak boleh berjalan bersamaan dengan $v_{3}, v_{5}, v_{6}, v_{11}, v_{12}$.

f. Arus $v_{9}$ tidak boleh berjalan bersamaan dengan $v_{2}, v_{3}, v_{5}, v_{6}, v_{11}, v_{12}$

g. Arus $v_{11}$ tidak boleh berjalan bersamaan dengan $v_{2}, v_{3}, v_{6}, v_{8}, v_{9}$

h. Arus $v_{12}$ tidak boleh berjalan bersamaan dengan $v_{2}, v_{3}, v_{5}, v_{6}, v_{8}, v_{9}$

Data traffic light di simpang 4 Gayam dari Dinas Perhubungan Kabupaten Sukoharjo sebagai berikut.

Tabel 7

Data sekunder simpang 4 Gayam

\begin{tabular}{|c|c|c|c|c|c|}
\hline $\begin{array}{c}\text { Kaki } \\
\text { simpang }\end{array}$ & Utara & $\begin{array}{c}\text { Timu } \\
\mathrm{r}\end{array}$ & $\begin{array}{c}\text { Sel } \\
\text { ata } \\
\mathrm{n}\end{array}$ & Barat & Total \\
\hline Merah & 95 & 89 & 99 & 89 & 372 \\
\hline Hijau & 21 & 27 & 17 & 27 & 92 \\
\hline Total & 116 & 116 & 116 & 116 & 464 \\
\hline
\end{tabular}

Langkah-langkah penyelesaian perhitungan traffic light di simpang 4 Gayam sebagai berikut:

1) Mentransformasi simpang 4 Gayam ke bentuk graf sebagai berikut:

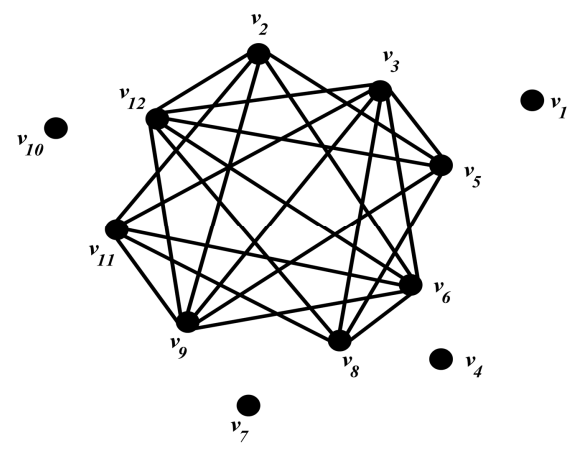

Gambar 10 Graf Simpang 4 Gayam

Dari transformasi graf di atas diketahui simpul $v_{1}, v_{4} v_{7}, v_{10}$, merupakan simpul asing, ini berarti arus yang dinyatakan $v_{1}, v_{4} v_{7}, v_{10}$ dapat berlangsung beriringan dengan arus lain. Jadi untuk arus yang dinyatakan oleh $v_{1}, v_{4} v_{7}, v_{10}$ selalu berlaku lampu hijau. Selanjutnya untuk simpul yang tersisa akan diberi warna dengan algoritma Welch Powell.

2) Mewarnai graf dengan algoritma Welch Powell untuk mencari bilangan kromatik.

Dengan menggunakan algoritma Welch Powell dihasilkan pewarnaan graf sebagai berikut:

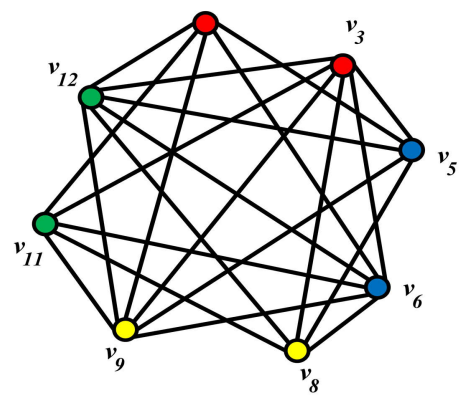

Gambar 11 Hasil pewarnaan graf pada simpang 4 Gayam

Dari pewarnaan graf di atas diperoleh bilangan kromatik $=4$ dan arus-arus yang dapat berjalan bersamaan sebagai berikut:

Tabel 8

Warna simpul graf pada simpang 4 Gayam

\begin{tabular}{|c|c|}
\hline Warna & Simpul \\
\hline Merah & $v_{2}, v_{3}$ \\
\hline Biru & $v_{5}, v_{6}$ \\
\hline Kuning & $v_{8}, v_{9}$ \\
\hline Hijau & $v_{11}, v_{12}$ \\
\hline
\end{tabular}

Dari Tabel 8, dapat dibentuk partisi pengautran lalu lintas sebagai berikut.

a. Partisi pertama, arus $v_{2}$ berjalan bersama dengan arus $v_{3}$

b. Partisi kedua, arus $v_{5}$ akan berjalan bersama arus $v_{6}$

c. Partisi ketiga, arus $v_{8}$ akan berjalan bersama arus $v_{9}$

d. Partisi keempat, arus $v_{11}$ akan berjalan bersama arus $v_{12}$

3) Menentukan alternatif penyelesaian durasi lampu merah dan lampu menyala.

Berdasarkan data sekunder simpang 4 Gayam yang memiliki durasi waktu satu siklus 116 detik, setelah dilakukan pembagian dengan bilangan kromatik $=4$, diperoleh durasi lampu hijau menyala yaitu 29 detik dan durasi lampu merah menyala yaitu 87 detik. Data traffic light baru hasil perhitungan disajikan pada Tabel 9 
Tabel 9. Penyelesaian traffic light simpang 4 Gayam

\begin{tabular}{|c|c|c|c|c|c|c|c|c|c|c|c|c|}
\hline Simpul & $v_{1}$ & $v_{2}$ & $v_{3}$ & $v_{4}$ & $v_{5}$ & $v_{6}$ & $v_{7}$ & $v_{8}$ & $v_{9}$ & $v_{10}$ & $v_{11}$ & $v_{12}$ \\
\hline Merah & 116 & 29 & 29 & 116 & 29 & 29 & 116 & 29 & 29 & 116 & 29 & 29 \\
\hline Hijau & 0 & 87 & 87 & 0 & 87 & 87 & 0 & 87 & 87 & 0 & 87 & 87 \\
\hline
\end{tabular}

Selanjutnya data baru untuk traffic light simpang 4 Gayam sebagai berikut.

Tabel10

Data baru traffic light simpang 4 Gayam

\begin{tabular}{|c|c|c|c|c|c|}
\hline $\begin{array}{c}\text { Kaki } \\
\mathrm{g}\end{array}$ & $\begin{array}{c}\text { Utar } \\
\mathrm{a}\end{array}$ & $\begin{array}{c}\text { Timu } \\
\mathrm{r}\end{array}$ & $\begin{array}{c}\text { Selata } \\
\mathrm{n}\end{array}$ & $\begin{array}{c}\text { Bara } \\
\mathrm{t}\end{array}$ & $\begin{array}{c}\text { Tota } \\
\mathrm{l}\end{array}$ \\
\hline Merah & 87 & 87 & 87 & 87 & 348 \\
\hline Hijau & 29 & 29 & 29 & 29 & 116 \\
\hline Total & 116 & 116 & 116 & 116 & 464 \\
\hline
\end{tabular}

Berdasarkan durasi lampu merah dan lampu hijau di simpang 4 Gayam dapat diketahui bahwa data baru hasil penyelesaian pewarnaan simpul dengan algoritma Welch Powell lebih efektif daripada data sekunder dari Dinas Perhubungan Kabupaten Sukoharjo tahun 2014. Berikut disajikan tabel data sekunder dan data baru.

Tabel 11

Data Sekunder dan data baru traffic light simpang 4 Gayam

\begin{tabular}{|c|c|c|c|c|}
\hline \multirow{2}{*}{$\begin{array}{c}\text { Kaki } \\
\text { Simpang }\end{array}$} & \multicolumn{2}{|c|}{$\begin{array}{c}\text { Data } \\
\text { Sekunder }\end{array}$} & \multicolumn{2}{c|}{ Data Baru } \\
\cline { 2 - 5 } & Merah & Hijau & Merah & Hijau \\
\hline Utara & 95 & 21 & 87 & 29 \\
\hline Timur & 89 & 27 & 87 & 29 \\
\hline Selatan & 99 & 17 & 87 & 29 \\
\hline Barat & 89 & 27 & 87 & 29 \\
\hline Total & $\mathbf{3 7 2}$ & $\mathbf{9 2}$ & $\mathbf{3 4 8}$ & $\mathbf{1 1 6}$ \\
\hline
\end{tabular}

Durasi total lampu hijau menyala dari data sekunder adalah 92 detik, sedangkan dengan pewarnaan simpul durasi total lampu hijau menyala adalah 116 detik. Tingkat efektivitasnya yaitu:

$$
=\frac{116 \quad 92}{92} \times 100 \%=26.09 \%
$$

Durasi total lampu merah menyala dari data sekunder adalah 372 detik, sedangkan dengan pewarnaan simpul durasi total lampu merah menyala adalah 348 detik. Tingkat efektivitasnya yaitu:
Jadi untuk kasus simpang 4 Gayam durasi lampu hijau menyala akan meningkat sebesar $26.09 \%$ sedangkan durasi lampu merah menyala dapat dikurangi sebesar $6.45 \%$.

\section{Simpang 5 Sukoharjo}

Berikut disajikan ilustrasi simpang 5 Sukoharjo

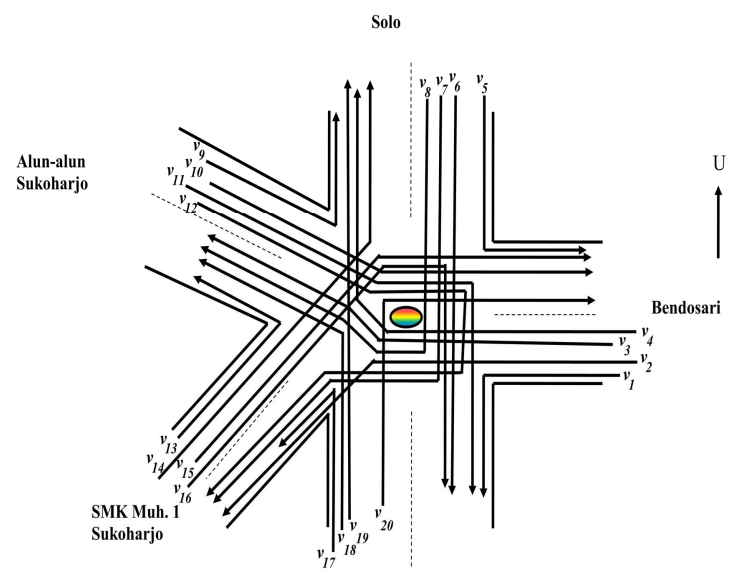

Gambar 12 Ilustrasi Arus Simpang 5 Sukoharjo Keterangan:

$v_{1}=$ arus dari Bendosari menuju Wonogiri $v_{2}=$ arus dari Bendosari menuju SMK Muh 1

Sukoharjo

$v_{3}=$ arus dari Bendosari menuju Alun-alun

Sukoharjo

$v_{4}=$ arus dari Bendosari menuju Solo

$v_{5}=$ arus dari Solo menuju Bendosari

$v_{6}=$ arus dari Solo menuju Wonogiri

$v_{7}=$ arus dari Solo menuju SMK Muh 1

Sukoharjo

$v_{8}=$ arus dari Solo menuju Alun-alun Sukoharjo

$v_{9}=$ arus dari Alun-alun Sukoharjo menuju Solo

$v_{10}=$ arus dari Alun-alun Sukoharjo menuju

Bendosari

$v_{11}=$ arus dari Alun-alun Sukoharjo menuju

Wonogiri

$v_{12}=$ arus dari Alun-alun Sukoharjo menuju SMK

Muh 1 Sukoharjo

$v_{13}=$ arus dari SMK Muh 1 Sukoharjo menuju

Alun-alun Sukoharjo 
$v_{14}=$ arus dari SMK Muh 1 Sukoharjo menuju

Solo

$v_{15}=$ arus dari SMK Muh 1 Sukoharjo menuju Bendosari

$v_{16}=$ arus dari SMK Muh 1 Sukoharjo menuju Wonogiri

$v_{17}=$ arus dari Wonogiri menuju SMK Muh 1

Sukoharjo

$v_{18}=$ arus dari Wonogiri menuju Alun-alun

Sukoharjo

$v_{19}=$ arus dari Wonogiri menuju Solo

$v_{20}=$ arus dari Wonogiri menuju Bendosari

Dengan menyelesaikan permasalahn di atas dengan pewarnaan graf diperoleh partisi pengaturan lampu lalu lintas sperti pada tabel 12 .

Tabel 12

Warna simpul graf pada simpang 5 Sukoharjo

\begin{tabular}{|c|c|}
\hline Warna & Simpul \\
\hline Biru & $v_{2}, v_{3}, v_{4}$ \\
\hline Ungu & $v_{6}, v_{7}, v_{8}$ \\
\hline Kuning & $v_{10}, v_{11}, v_{12}$ \\
\hline Merah & $v_{14}, v_{15}, v_{16}$ \\
\hline Hijau & $v_{18}, v_{19}, v_{20}$ \\
\hline
\end{tabular}

Berdasrkan Tabel 12, partisi yang dibuat, yaitu:

a. Partisi pertama, arus $v_{2}$ berjalan bersama dengan arus $v_{3}$ dan $v_{4}$

b. Partisi kedua, arus $\mathrm{v}_{6}$ akan berjalan bersama arus $\mathrm{v}_{7}$ dan $\mathrm{v}_{8}$

c. Partisi ketiga, arus v10 akan berjalan bersama arus $\mathrm{v}_{11}$ dan $\mathrm{v}_{12}$

d. Partisi keempat, arus v14 akan berjalan bersama arus $\mathrm{v}_{15}$ dan $\mathrm{v}_{16}$

e. Partisi kelima, arus v18 akan berjalan bersama arus $\mathrm{v}_{19}$ dan $\mathrm{v}_{20}$
Berdasarkan data sekunder traffic light simpang 5 Sukoharjo durasi waktu satu siklus 131 detik, setelah dilakukan pembagian dengan bilangan kromatik $=5$, diperoleh durasi lampu hijau menyala yaitu 26.2 detik dan durasi lampu merah menyala yaitu 104.8 detik. Data traffic light baru hasil perhitungan disajikan pada Tabel 13.

Selanjutnya data baru untuk traffic light simpang 5 Sukoharjo disajikan pada Tabel 14.

Berdasarkan durasi lampu merah dan lampu hijau di simpang 5 Sukoharjo dapat diketahui bahwa data baru hasil penyelesaian pewarnaan simpul dengan algoritma Welch Powell lebih efektif daripada data sekunder dari Dinas Perhubungan Kabupaten Sukoharjo tahun 2014. Pada Tabel 15 disajikan perbandingan data baru dengan data sekunder.

Durasi total lampu hijau menyala dari data sekunder adalah 110 detik, sedangkan dengan pewarnaan simpul durasi total lampu hijau menyala adalah 131 detik. Tingkat efektivitasnya yaitu:

$$
\text { Hijau }=\frac{131 \quad 110}{110} \times 100 \%=19.09 \%
$$

Durasi total lampu merah menyala dari data sekunder adalah 545 detik, sedangkan dengan pewarnaan simpul durasi total lampu merah menyala adalah 524 detik. Tingkat efektivitasnya yaitu:

$$
\text { Merah }=\frac{545524}{545} \times 100 \%=3.85 \%
$$

Jadi untuk kasus simpang 5 Sukoharjo durasi lampu hijau menyala akan meningkat sebesar $19.09 \%$ sedangkan durasi lampu merah menyala dapat dikurangi sebesar $3.85 \%$.

Tabel 13

\begin{tabular}{|c|c|c|c|c|c|c|c|c|c|c|}
\hline Simpul & $v_{1}$ & $v_{2}$ & $v_{3}$ & $v_{4}$ & $v_{5}$ & $v_{6}$ & $v_{7}$ & $v_{8}$ & $v_{9}$ & $v_{10}$ \\
\hline Merah & 0 & 104.8 & 104.8 & 104.8 & 0 & 104.8 & 104.8 & 104.8 & 0 & 104.8 \\
\hline Hijau & 131 & 26.2 & 26.2 & 26.2 & 131 & 26.2 & 26.2 & 26.2 & 131 & 26.2 \\
\hline Total & 131 & 131 & 131 & 131 & 131 & 131 & 131 & 131 & 131 & 131 \\
\hline
\end{tabular}

Penyelesaian traffic light simpang 5 Sukoharjo

\begin{tabular}{|l|r|r|r|r|r|r|r|r|r|r|}
\hline Simpul & \multicolumn{1}{|c|}{$v_{11}$} & \multicolumn{1}{|c|}{$v_{12}$} & \multicolumn{1}{|c|}{$v_{13}$} & \multicolumn{1}{c|}{$v_{14}$} & \multicolumn{1}{c|}{$v_{15}$} & \multicolumn{1}{c|}{$v_{16}$} & \multicolumn{1}{c|}{$v_{17}$} & \multicolumn{1}{c|}{$v_{18}$} & \multicolumn{1}{c|}{$v_{19}$} & \multicolumn{1}{c|}{$v_{20}$} \\
\hline Merah & 104.8 & 104.8 & 0 & 104.8 & 104.8 & 104.8 & 0 & 104.8 & 104.8 & 104.8 \\
\hline Hijau & 26.2 & 26.2 & 131 & 26.2 & 26.2 & 26.2 & 131 & 26.2 & 26.2 & 26.2 \\
\hline Total & 131 & 131 & 131 & 131 & 131 & 131 & 131 & 131 & 131 & 131 \\
\hline
\end{tabular}

Tabel 14 Data baru traffic light simpang 5 Sukoharjo

\begin{tabular}{|c|r|r|r|r|r|c|}
\hline Kaki simpang & Barat Laut & \multicolumn{1}{c|}{ Barat Daya } & Timur & Selatan & Utara & Total \\
\hline Merah & 104.8 & 104.8 & 104.8 & 104.8 & 104.8 & 524 \\
\hline Hijau & 26.2 & 26.2 & 26.2 & 26.2 & 26.2 & 131 \\
\hline
\end{tabular}




\begin{tabular}{|l|r|r|r|r|r|r|}
\hline Total & 131 & 131 & 131 & 131 & 131 & 655 \\
\hline
\end{tabular}

Tabel 15 Data Sekunder dan data baru traffic light simpang 5 Sukoharjo

\begin{tabular}{|c|c|c|c|c|}
\hline \multirow{2}{*}{ Kaki Simpang } & \multicolumn{2}{|c|}{ Data Sekunder } & \multicolumn{2}{c|}{ Data Baru } \\
\cline { 2 - 5 } & Merah & Hijau & Merah & Hijau \\
\hline Barat Laut & 109 & 22 & 104.8 & 26.2 \\
\hline Barat Daya & 119 & 12 & 104.8 & 26.2 \\
\hline Timur & 109 & 22 & 104.8 & 26.2 \\
\hline Selatan & 99 & 32 & 104.8 & 26.2 \\
\hline Utara & 109 & 22 & 104.8 & 26.2 \\
\hline Total & $\mathbf{5 4 5}$ & $\mathbf{1 1 0}$ & $\mathbf{5 2 4}$ & $\mathbf{1 3 1}$ \\
\hline
\end{tabular}

\section{KESIMPULAN DAN SARAN \\ Kesimpulan}

Berdasarkan penjelasan yang telah diuraikan sebelumnya, maka dapat diperoleh kesimpulan sabagai berikut:

1. Pewarnaan simpul dengan algoritma Welch Powell dapat diaplikasikan untuk menyelesaikan perhitungan durasi waktu pada traffic light. Langkah yang ditempuh yaitu dengan mentransformasi persimpangan jalan beserta arusnya ke bentuk graf. Simpul merepresentasikan arus dan garis merepresentasikan arus yang uncompatible. Selanjutnya mewarnai simpul pada graf dengan algoritma Welch Powell untuk mengetahui arus yang dapat berjalan bersamaan dan memperoleh bilangan kromatik yang berfungsi untuk menentukan alternatif penyelesaian durasi waktu traffic light. Berdasarkan durasi lampu merah dan lampu hijau di beberapa persimangan di Sukoharo dapat diketahui bahwa data baru hasil penyelesaian pewarnaan simpul dengan algoritma Welch Powell lebih efektif daripada data sekunder dari Dinas Perhubungan Kabupaten Sukoharjo tahun 2014.

2. Penyelesaian perhitungan durasi waktu pada traffic light dengan pewarnaan simpul memberikan alternatif hasil yang lebih efektif dibandingkan data sekunder dari Dinas Perhubungan Kabupaten Sukoharjo tahun 2014.

\section{Saran}

Penelitian ini dapat dikembangkan dengan menambahkan program komputer agar penyelesaian masalah pewarnaa simpul pada traffic light menjadi lebih singkat.

\section{DAFTAR PUSTAKA}

Detty Purnamasari, Muhammad Zidni Ilman, \& Dessy Wulandari A.P. 2012. "Algoritma WelchPowell untuk Pengendalian Lampu Lalu Lintas”. UG Jurnal. 6(03): 26-33.

Koh Khee Meng, Dong Fengming dan Tay Eng Guan. Introduction to Graph Theory. Singapore: World Scientific.

Jong Jek Siang. 2002. Matematika Diskrit dan Aplikasinya pada Ilmu Komputer.Yogyakarta: Andi.

Joan M. Aldous dan Robin J.Wilson. 1996. Introduction to Graph Theory. Practice Hall.

Munir, Rinaldi. 2005. Matematika Diskrit. Bandung: Informatika.

Richard Johnsonbaugh. 2002. Matematika Diskrit. Jakarta: PT Prenhallindo.

Riwinoto, R. Yugo Kartono Isal. 2010. Simulasi Optimasi Pengaturan Lampu Lalu Lintas di Kota Depok dengan Menggunakan Pendekatan Greedy Berbasis Graf. Prosiding Seminar Nasional Sistem dan Informatika 2010, 13 November 13, 2010. Bali. 